\title{
Aplikasi Absensi Online Berbasis Android
}

\author{
Panji Rachmat Setiawan \\ Jurusan Teknik Informatika, Fakultas Teknik, Universitas Islam Riau \\ panji.r.setiawan@eng.uir.ac.id
}

\begin{tabular}{l}
\hline \hline Article Info \\
\hline History: \\
Dikirim 06 Juni 2020 \\
Direvisi 18 Juni 2020 \\
Diterima 14 Juli 2020 \\
\hline
\end{tabular}

\section{Kata Kunci:}

Absensi

Konvensional

Teknologi

Kecurangan

Android

\begin{abstract}
Abstrak
Perkembangan teknologi mengalami kemajuan yang pesat pada zaman sekarang. Terutama perkembangan pada ilmu Teknologi Informasi. Hal ini dapat dilihat dari kehidupan sehari - hari bagaimana masyarakat Indonesia pada umumnya selalu melibatkan teknologi dalam melaksanakan kegiatan sehari - hari. Tetapi masih jarang yang memanfaatkan teknologi dalam membantu pekerjaan maupun memenuhi kebutuhan pekerjaan. Masih banyaknya pekerjaan yang seharusnya sudah dapat dilakukan dengan cara memanfaatkan teknologi, tetapi masih menggunakan hal-hal yang bersifat konvensional dalam melakukan pekerjaan maupun menghimpun data yang dibutuhkan. Tak jarang pula kegiatan absensi menjadi bagian penilaian antara dosen kepada mahasiswa, yang mana mempengaruhi dari hasil nilai akhir yang diterima oleh mahasiswa. Dan sering terjadi kecurangan yang dilakukan oleh para mahasiswa terkait dengan absensi agar dapat memenuhi angka minimal kehadiran pada kegiatan belajar mengajar. Titip absen yang dilakukan antar mahasiswa adalah hal yang lumrah terjadi. Hal ini dapat merugikan dosen, mahasiswa yang lain, dan juga mahasiswa yang melakukan kegiatan titip absen tersebut. Lembar absensi yang digunakan untuk absensi mahasiswa pun sering terjadi kerusakan, padahal nantinya lembar absensi ini akan dijadikan laporan terkait kegiatan beljar-mengajar pada satu semester dilakukan. Apabila dokumen tersebut rusak, maka akan mempengaruhi proses pengecekan dokumen yang dilakukan oleh pihak universitas.
\end{abstract}

(C) This work is licensed under a Creative Commons Attribution-ShareAlike 4.0 International License.

\author{
Koresponden: \\ Panji Rachmat Setiawan \\ Program Studi Teknik Informatika, Fakultas Teknik \\ Universitas Islam Riau \\ Alamat, Kota, Negara, Kode Pos \\ Email : panji.r.setiawan@eng.uir.ac.id
}

\section{PENDAHULUAN}

Perkembangan teknologi mengalami kemajuan yang pesat pada zaman sekarang. Terutama perkembangan pada ilmu Teknologi Informasi. Hal ini dapat dilihat dari kehidupan sehari - hari bagaimana masyarakat Indonesia pada umumnya selalu melibatkan teknologi dalam melaksanakan kegiatan sehari - hari. Tetapi masih jarang yang memanfaatkan teknologi dalam membantu pekerjaan maupun memenuhi kebutuhan dalam pekerjaan. Masih banyaknya pekerjaan yang seharusnya sudah dapat dilakukan dengan cara memanfaatkan teknologi, tetapi masih menggunakan hal - hal yang bersifat konvensional dalam melakukan pekerjaan maupun menghimpun data yang dibutuhkan. 
Tak jarang pula kegiatan absensi menjadi bagian penilaian antara dosen kepada mahasiswa, yang mana mempengaruhi dari hasil nilai akhir yang diterima oleh mahasiswa. Dan sering terjadi kecurangan yang dilakukan oleh para mahasiswa terkait dengan absensi agar dapat memenuhi angka minimal kehadiran pada kegiatan belajar mengajar. Titip absen yang dilakukan antar mahasiswa adalah hal yang lumrah terjadi. Hal ini dapat merugikan dosen, mahasiswa yang lain, dan juga mahasiswa yang melakukan kegiatan titip absen tersebut. Lembar absensi yang digunakan untuk absensi mahasiswa pun sering terjadi kerusakan, padahal nantinya lembar absensi ini akan dijadikan laporan terkait kegiatan belajar-mengajar pada satu semester dilakukan. Apabila dokumen tersebut rusak, maka akan mempengaruhi proses pengecekan dokumen yang dilakukan oleh pihak universitas.

Melihat permasalahan di atas, penulis melakukan penelitian untuk menghindari kegiatan absensi yang dapat merugikan pihak mahasiswa dan dosen, serta terhindari dari kerusakan dokumen.

\section{METODE PENELITIAN}

\subsection{Tinjauan Penelitian}

Seperti halnya penelitian yang dilakukan oleh Husain dkk [1], mengatakan bahwa pada saat ini perusahaan membutuhkan suatu sistem absensi yang bersifat efisien, efektif, dan cepat. Pengembangan dilakukan dengan memanfaatkan device android yang dimiliki oleh setiap karyawan, serta dengan menggunakan jaringan local yang berjarak hanya di dalam lingkungan perusahaan, hal ini dilakukan untuk menghindari kegiatan karyawan yang melakukan absensi di luar dari perusahaan.

Rujukan penelitian selanjutnya adalah penelitian yang dilakukan oleh Aini dkk [2], menyatakan bahwa penerapan absensi dengan menggunakan QRCode dapat menghindari dari terjadinya kecurangan dalam proses absensi seperti titip absen. Hal ini dikarenakan dalam penggunaan sistem absensi tersebut, maka dapat menyimpan data berupa Nomor Induk Mahasiswa, Dosen, Ruang Perkuliahan, dan Waktu Perkuliahan.

Rujukan penelitian selanjutnya, menurut Fitri [3], dalam penelitian yang dilakukan telah menghasilkan sebuah aplikasi sistem absensi online berbasis android, berkaitan dengan simulasi sistem admin dan simulasi pengisian KRS. Mahasiswa dapat melakukan absensi secara online untuk menghasilkan output waktu pada saat absen dan dosen dapat memantau serta mengontrol proses absensi mahasiswa melalui aplikasi android.

Penulis juga melakukan tinjauan Pustaka terhadap penelitian yang dilakukan oleh Ronny dkk, yang mana mereka berhasil menciptakan suatu sistem aplikasi absensi dengan menggunakan metode lock GPS dengan Android pada PT. PLN APP Malang [4]. Dengan adanya aplikasi ini, para pegawai yang ada pada PT. PLN dapat terbantukan melakukan absensi tanpa harus mendatangi tempat absensi yang memiliki jarak yang cukup jauh. Absensi dapat dilakukan pada saat pegawai berada di wilayah kerjanya, hal ini menggunakan teknologi GPS Lock.

Taufik Ramadhan, dalam judul penelitian nya adalah, "Rancang Bangun Aplikasi Mobile Untuk Notifikasi Jadwal Kuliah Berbasis Android" [5] menjelaskan bahwa penggunaan dari website dan papan pengumuman untuk jadwal kuliah, disebut kurang efektif bagi mahasiswa. Dikarenakan informasi yang diberikan belum tentu dapat sampai dengan cepat dan tepat kepada mahasiswa. Maka dari itu, peneliti mengemabangkan suatu aplikasi yang dijalankan pada perangkat android, dengan tujuan memberikan informasi mengenai perkuliahan yang akan diberikan langsung kepada mahasiswa melalui perangkat android masing - masing.

Dalam mengumpulkan data, penulis langsung mendatangi instansi yang terkait dan melakukan wawancara, serta melakukan observasi secara langsung. Data yang sudah penulis peroleh nantinya akan penulis gunakan sebagai dasar pengembangan aplikasi ini. Untuk contoh kasus, penulis akan melihat dalam sebulan, berapa banyak kasus kesalahan dalam absensi terjadi, seberapa besar dampak dari kesalahan, dan apa saja kerugian yang akan diterima baik oleh mahasiswa maupun dari pihak dosen dan universitas.

Adapun metode pengumpulan data yang penulis lakukan adalah: 


\section{Wawancara}

Menurut [6], pengertian wawancara adalah suatu percakapan dengan tujuan - tujuan tertentu. Penulis berhadapan langsung dengan responden, dalam hal ini adalah pihak dari instansi (face to face) untuk mendapatkan informasi secara lisan berupa kasus absensi yang dihadapi dosen dan mahasiswa, dan menjadi bahan pengembangan sistem aplikasi.

\section{Observasi}

Menurut [7] dalam Zuriah, observasi diartikan sebagai pengamatan dan pencatatan secara sistematis terhadap gejala yang tampak pada obyek penelitian. Penulis melakukan observasi langsung kepada instansi - instansi yang mengalami kesulitan dalam menjalankan proses absensi. Hasil dari observasi ini penulis gunakan sebagai bahan penelitian.

3. Studi Kepustakaan

Selain wawancara dan observasi, penulis juga akan melakukan studi kepustakaan, dengan cara melihat penelitian sebelumnya, mencari keunggulan dari penelitian sebelumnya, serta menggunakan kesimpulan dari penelitian sebelumnya untuk pengembangan dari penelitian yang penulis lakukan.

\subsection{Konsep Operasional}

Merujuk kepada permasalahan dari penelitian yang penulis paparkan, serta dari Teknik pengumpulan data yang penulis berikan, maka secara operasional berjalan penelitian ini adalah sebagai berikut:

1. Penulis mendatangi universitas yang terkait dalam penelitian.

2. Penulis melakukan wawancara kepada pihak universitas dalam hal ini dosen, serta melakukan observasi secara langsung terkait dengan kasus - kasus yang dihadapi oleh masing - masing divisi.

3. Data yang penulis dapatkan, berupa kasus - kasus yang terkait dengan absensi yang dihadapi oleh beberapa program studi.

4. Setelah data didapatkan, maka langkah selanjutnya adalah penulis melakukan pengembangan aplikasi sesuai dengan data kasus yang penulis dapatkan.

5. Dalam pengembangan aplikasi, penulis melakukan pengembangan dari 4 sudut pandang, dari mahasiswa, dosen, pegawai universitas (pegawai yang terkait dalam urusan absensi), pimpinan masing - masing program studi.

6. Setelah pengembangan selesai dilakukan, penulis melakukan uji coba, serta penulis melakukan implementasi terhadap masing - masing program studi.

\section{HASIL DAN PEMBAHASAN}

Pada bagian ini, penulis akan menjelaskan kebutuhan dari sistem yang dirancang. Berdasarkan Analisa yang dihasilkan, dilanjutkan dengan perancangan yang terdiri atas perancangan aplikasi, basis data, serta perancangan antarmuka sistem.

\subsection{Flow Chart}

Penulis mengembangkan alur dari sistem yang akan dikembangkan melalui diagram flowchart. Pada diagram flowchart terdapat beberapa rancangan sistem yang penulis kembangkan. 


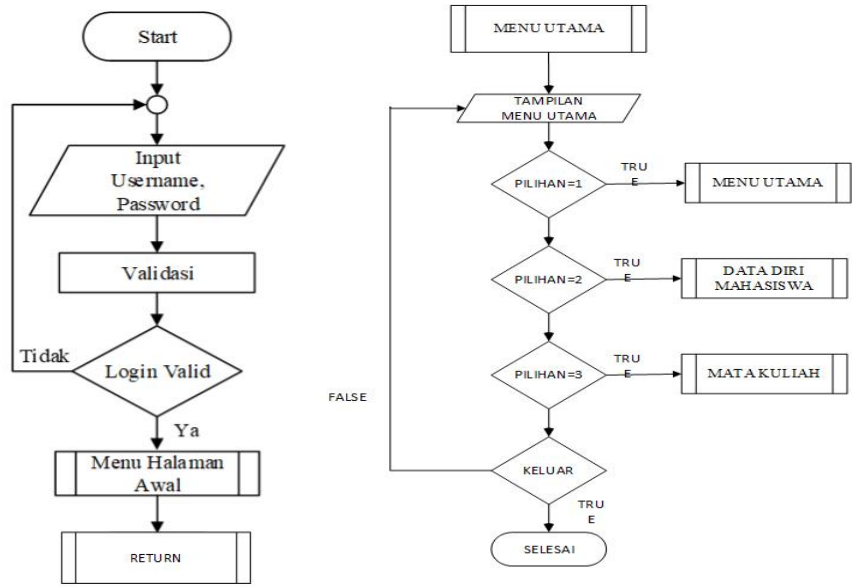

FLOW CHART LOG IN

Gambar 1. Login.
FLOW CHART MENU
UTAMA MAHASISWA

Gambar 2. Menu Utama.

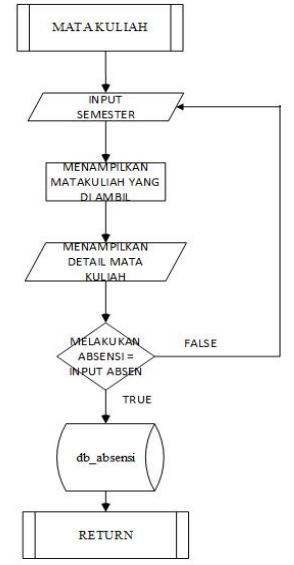

Gambar 3. Proses Absensi.

Pada flowchart login, terdapat suatu kegiatan sebelum mahasiswa dapat menggunakan sistem untuk kegiatan absensi. Pada tahapan pertama, mahasiswa akan diminta untuk memasukan username dan password yang mana adalah NPM dari mahasiswa untuk username nya, dan tanggal lahir dari si mahasiswa untuk password. Setelah itu sistem akan melakukan validasi, apabila mahasiswa terdaftar pada sistem, maka mahasiswa akan dibawa masuk pada menu utama. Dan seandainya mahasiswa tidak terdaftar, maka tidak dapat masuk ke menu utama, dan si mahasiswa diminta untuk mendaftarkan dirinya terlebih dahulu pada universitas.

Flowchart Menu Utama menggambarkan keadaan pada saat mahasiswa berhasil divalidasi oleh sistem, dan berada pada beberapa pilihan. Mahasiswa dapat memilih menu sesuai dengan kebutuhan, apakah ingin melihat data diri yang sudah didaftarkan, atau ingin masuk ke menu absensi untuk melakukan absensi sesuai dengan matakuliah yang diambil.

Pada flowchart proses absensi, mahasiswa akan memilih semester yang diambil, apakah tahun ajaran ganjil, atau tahun ajaran genap. Setelah memilih tahun ajaran, aplikasi akan menampilkan matakuliah yang sedang diambil oleh mahasiswa yang bersangkutan. Disaat memasuki kelas diadakannya perkuliahan, apllikasi akan menangkap sinyal Bluetooth yang ada di kelas, dan memberikan notifikasi kepada mahasiswa, bahwasanya absensi sudah berhasil dilakukan, dan notifikasi akan masuk kedalam aplikasi yang digunakan oleh dosen, menyatakan bahwa mahasiswa yang bersangkutan sudah masuk ke kelas tersebut.

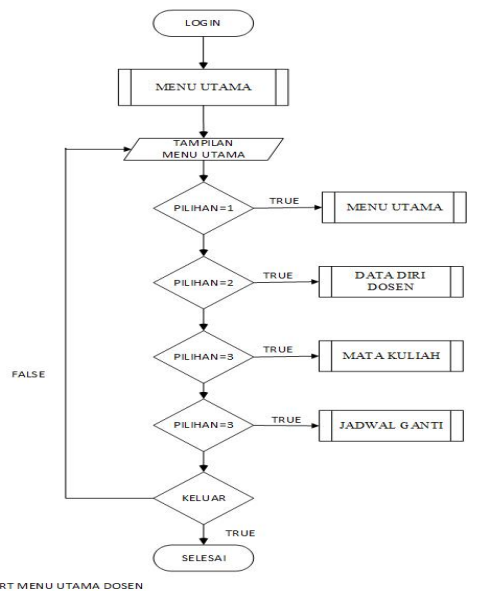

Gambar 4. Menu Utama Dosen.

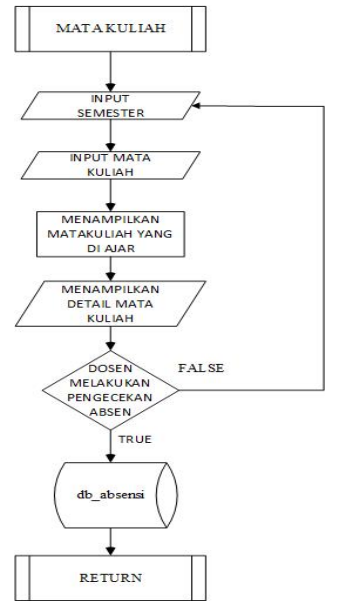

Gambar 5. Menu Matakuliah Yang Diampu Dosen. 
Flowchart berikutnya menggambarkan menu utama yang dimiliki oleh dosen. Sebelum dosen dapat mengakses menu utama dari aplikasi ini, harus melewati proses validasi terlebih dahulu. Pada menu utama, dosen dapat melakukan pilihan sesuai kebutuhan, seperti melihat data diri dosen yang didaftarkan, mata kuliah yang diampu oleh dosen yang bersangkutan, dan apabila dosen ingin melakukan jadwal ganti, maka dapat melakukan perpindahan jadwal pada menu yang telah disediakan.

Flowchart berikutnya adalah flowchart menu matakuliah yang ada pada aplikasi milik dosen, menjelaskan bahwa dosen dapat melihat absensi yang dilakukan oleh para mahasiswa, sesuai dengan semester dan sesuai dengan tahun ajaran yang dipilih, matakuliah yang diampu, dan minggu perkuliahan berlangsung.

Apabila dosen ingin mengganti jadwal kuliah, dikarenakan ada halangan untuk hadir, ataupun hari libur yang disebabkan oleh tanggal merah, maka dosen yang bersangkutan dapat mengganti jadwal perkuliahan pada sistem, dengan memilih mengganti jadwal, semester yang diajar sesuai dengan tahun ajar yang dipilih, matakuliah yang ingin diganti jadwalnya, memberikan informasi jadwal baru, dan mengubah jadwal. Setelah itu sistem akan memberikan notifikasi terhadap dosen bahwasanya jadwal berhasil diganti, dan notifikasi juga diberikan kepada mahasiswa yang mengambil matakuliah dosen yang bersangkutan.

\subsection{Rancangan Aplikasi}

Rancangan aplikasi pada sistem absensi online berbasis android ini melibatkan 6 fitur yang akan digunakan baik oleh dosen dan para mahasiswa. Fitur - fitur yang terlibat adalah Login, Matakuliah, Detail Matakuliah, Jadwal Matakuliah Dosen, Detail Jadwal Dosen, dan Absensi Mahasiswa. Adapun rancangan dari aplikasi dapat dilihat pada gambar 6.

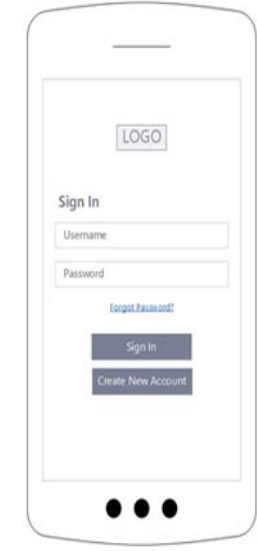

A

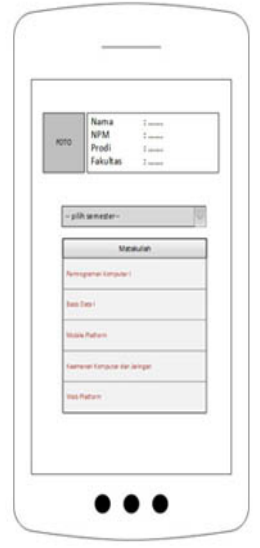

B

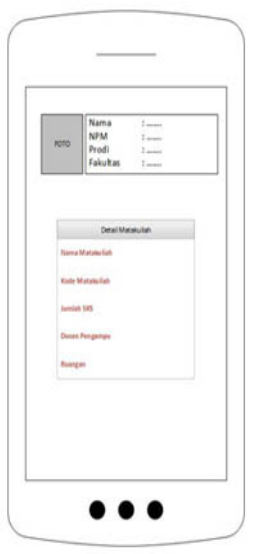

$\mathrm{C}$

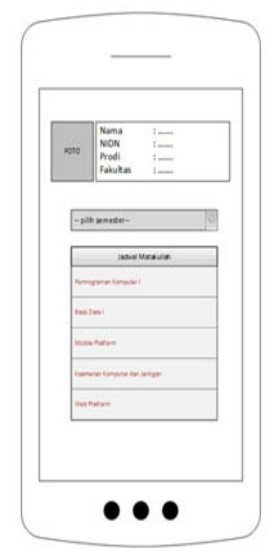

D

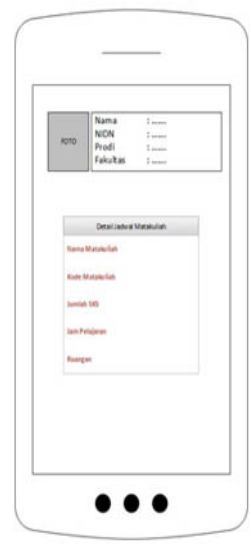

E

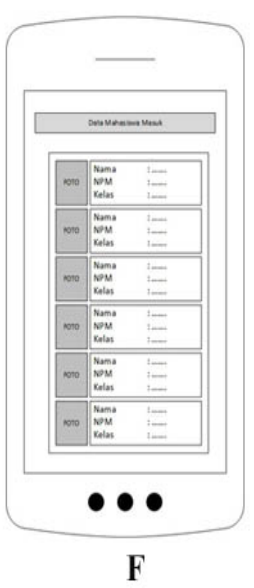

F

Gambar 6. A. Login, B. Matakuliah, C. Detail Matakuliah, D. Jadwal Matakuliah Dosen, E. Detail Jadwal Dosen, F. Absensi Mahasiswa

\subsection{Entity Relationship Diagram (ERD)}

Perancangan basis data yang dilakukan sesuai dengan kebutuhan sistem yang dibutuhkan. Pada penggunaan basis data, menggunakan 5 tabel, yang terdiri dari table Dosen, table MataKuliah, table Jadwal, table Ruangan, dan table Mahasiswa. Untuk rancangan dari database dapat dilihat pada gambar 7. 


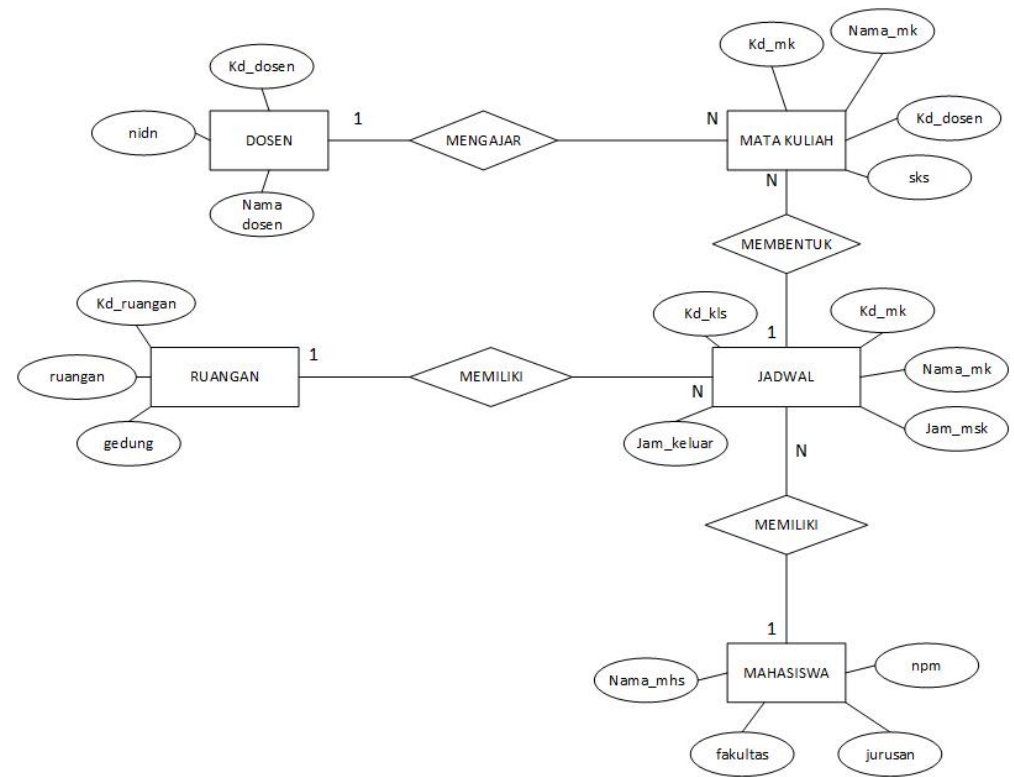

Gambar 7. Rancangan Database Dalam Bentuk Entity Relationship Diagram (ERD).

Berikutnya, rancangan dari antar muka dilakukan sesuai dengan rancangan dari aplikasi yang sudah dilakukan. Aplilkasi akan digunakan pada perangkat android, maka dari itu rancangan dari antar muka merupakan rancangan yang akan digunakan pada perangkat android. Penulis akan menjelaskan setiap bagian atau fitur yang telah diimplementasi pada aplikasi absensi online berbasis android ini.

\subsection{Halaman Login, Jadwal Matakuliah dan Detail Matakuliah}

Pada halaman login, pengguna akan memberikan informasi mengenai username dan password yang sudah didaftarkan. Apakah pengguna masuk sebagai mahasiswa, atau pengguna masuk sebagai dosen. Halaman login dapat dilihat pada gambar 8. Pada halaman jadwal matakuliah, mahasiswa dapat melihat jadwal matakuliah yang sudah diambil ataupun yang sedang diambil secara keseluruhan sesuai dengan semester yang diinginkan. Halaman jadwal matakuliah mahasiswa dapat dilihat pada gambar 9. Pada halaman detail matakuliah, mahasiswa dapat melihat secara detail matakuliah yang diambil. Isi dari detail matakuliah ini adalah nama matakuliah, kode matakuliah, jumlah sks matakuliah, dosen pengampu matakuliah, dan jadwal ruangan matakuliah. Halaman detail matakuliah dapat dilihat pada gambar 10.

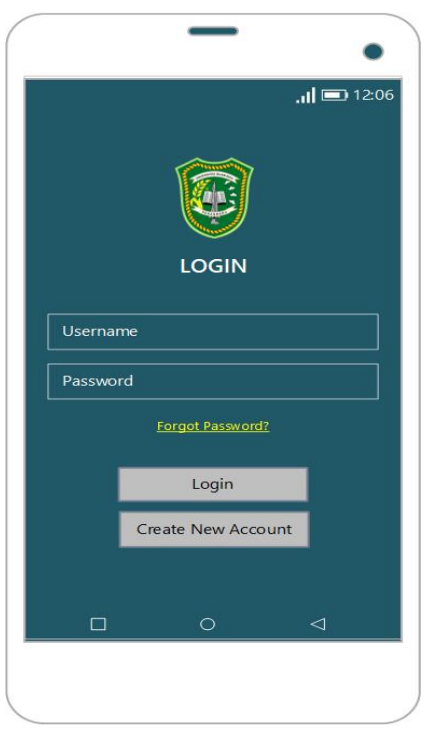

Gambar 8. Login.

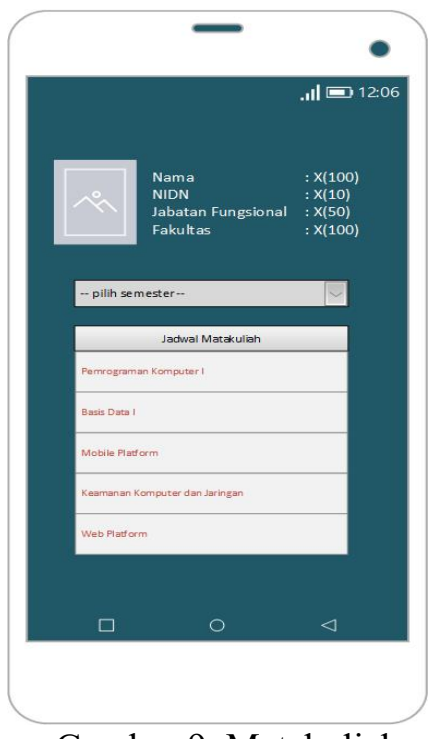

Gambar 9. Matakuliah.

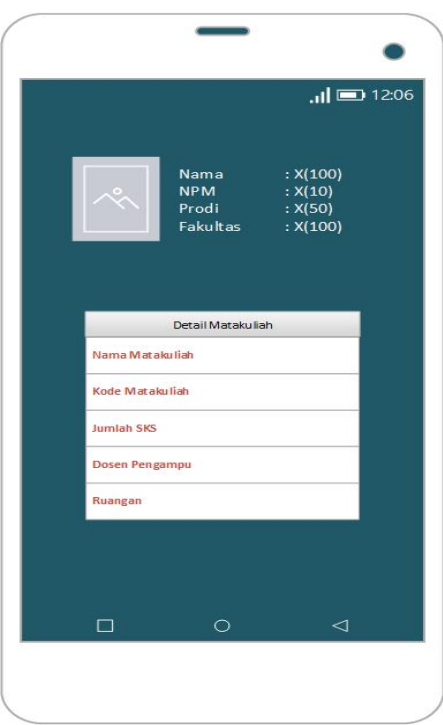

Gambar 10. Detail Matakuliah. 


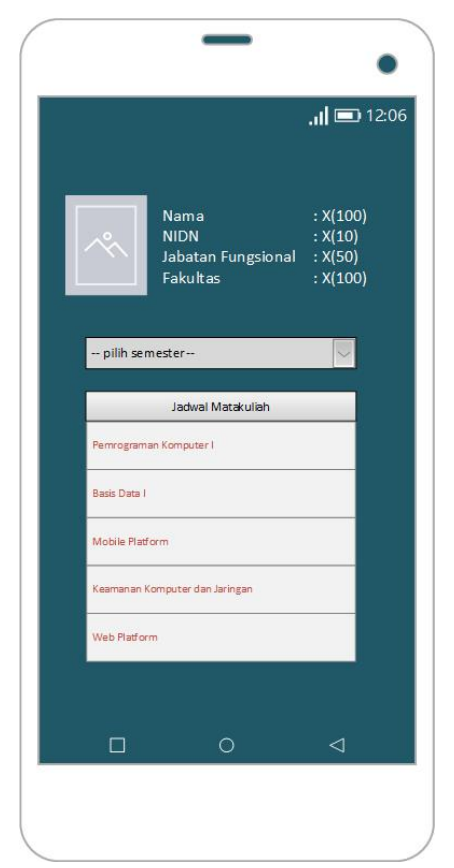

Gambar 11. Jadwal Dosen.

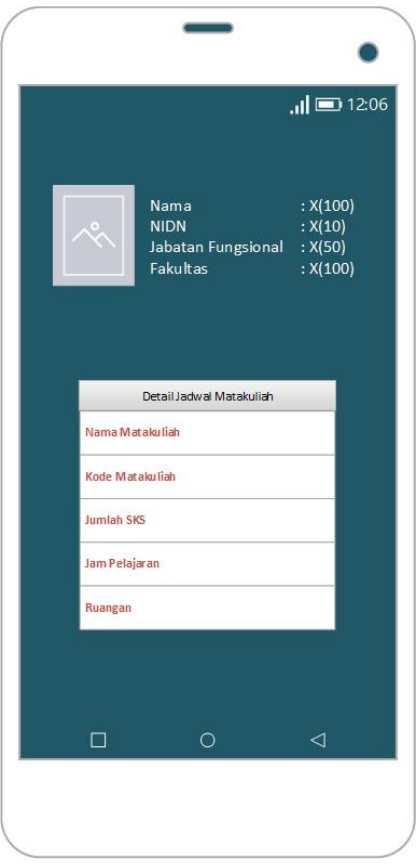

Gambar 12. Detail.

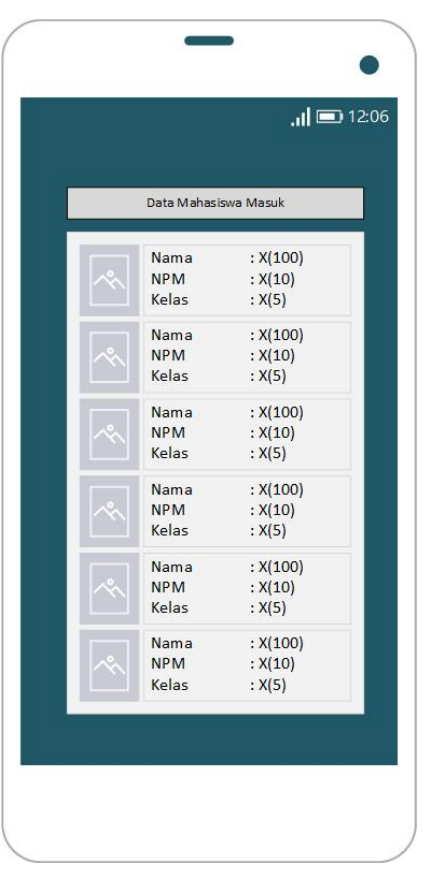

Gambar 13. Data Absen.

\subsection{Halaman Jadwal Matakuliah Dosen, Detail Matakuliah Dosen, dan Data Mahasiswa Absen}

Halaman jadwal matakuliah dosen berisi mengenai jadwal matakuliah yang sudah maupun yang sedang diampu oleh dosen yang bersangkutan. Jadwal dapat dipilih berdasarkan tahun ajaran yang diinginkan. Dapat dilihat pada gambar 11. Pada halaman detail matakuliah dosen, terdapat informasi detail mengenai matakuliah yang sedang diampu oleh dosen yang bersangkutan. Informasi yang disajikan berupa nama matakuliah, kode matakuliah, jumlah sks pada matakuliah yang bersangkutan, dan ruangan tempat dilaksanakanya perkuliahan terkait matakuliah yang diampu. Dapat dilhat pada gambar 12. Halaman data mahasiswa absen berisikan data mahasiswa yang sudah melakukan absen pada jam matakuliah yang sedang berlangsung. Informasi yang didapatkan dari halaman ini adalah nama mahasiswa, NPM, dan kelas dimana mahasiswa tersebut melakukan pendaftaran KRS. Dapat dilihat pada gambar 13.

\subsection{Pengujian Aplikasi}

Pengujian merupakan hal terpenting yang bertujuan untuk menemukan kesalahan - kesalahan pada sistem sebelum sistem diterapkan. Pengujian bermaksud untuk memastikan apakah sistem yang telah dibuat sudah berjalan seperti yang diharapkan atau tidak.

Adapun teknik pengujian yang dilakukan yaitu menggunakan metode pengujian black box, yang mana pengujiannya hanya difokuskan pada fungsi dari aplikasi yang telah dibuat. Sebelum melakukan pengujian aplikasi maka perlu adanya perencanaan pengujian. Adapun gambaran perencanaan pengujian melalui black box dapat dilihat pada table 1

Tabel 1. Perencanaan Pengujian Tampilan Antarmuka.

\begin{tabular}{|c|c|c|c|}
\hline No & Kelas Uji & $\begin{array}{c}\text { Detail } \\
\text { Penguiian }\end{array}$ & $\begin{array}{c}\text { Jenis } \\
\text { Penguijian }\end{array}$ \\
\hline 1 & Login & $\begin{array}{l}\text { Verifikasi } \\
\text { Username dan } \\
\text { Password }\end{array}$ & Black Box \\
\hline 2 & $\begin{array}{c}\text { Jadwal } \\
\text { Matakuliah } \\
\text { Mahasiswa }\end{array}$ & $\begin{array}{l}\text { Verifikasi data } \\
\text { matakuliah } \\
\text { yang diambil } \\
\text { mahasiswa }\end{array}$ & Black Box \\
\hline
\end{tabular}




\begin{tabular}{|c|c|c|c|}
\hline 3 & $\begin{array}{c}\text { Detail } \\
\text { Matakuliah } \\
\text { Mahasiswa }\end{array}$ & $\begin{array}{c}\text { Verifikasi data } \\
\text { detail } \\
\text { matakuliah } \\
\text { yang diambil } \\
\text { mahasiswa }\end{array}$ & Black Box \\
\hline 4 & $\begin{array}{c}\text { Jadwal } \\
\text { Matakuliah } \\
\text { Dosen }\end{array}$ & $\begin{array}{l}\text { Verifikasi data } \\
\text { matakuliah } \\
\text { yang diampu } \\
\text { dosen }\end{array}$ & Black Box \\
\hline 5 & $\begin{array}{l}\text { Detail Jadwal } \\
\text { Matakuliah } \\
\text { Dosen }\end{array}$ & $\begin{array}{l}\text { Verifikasi data } \\
\text { detail } \\
\text { matakuliah } \\
\text { yang diampu } \\
\text { dosen }\end{array}$ & Black Box \\
\hline 6 & $\begin{array}{c}\text { Data } \\
\text { Mahasiswa } \\
\text { Absen }\end{array}$ & $\begin{array}{l}\text { Verifikasi data } \\
\text { mahasiswa } \\
\text { yang } \\
\text { mengikuti } \\
\text { perkuliahan }\end{array}$ & Black Box \\
\hline
\end{tabular}

\section{KESIMPULAN}

Berdasarkan penelitian yang telah dilakukan mengenai aplikasi absensi online berbasis android ini, maka dapat diambil kesimpulan sebagai berikut:

1. Aplikasi absensi online berbasis android ini dibangun untuk memberikan kemudahan dalam melaksanakan kegiatan absensi antar mahasiswa dan dosen di dalam kelas perkuliahan sesuai dengan jadwal yang telah ditentukan.

2. Aplikasi ini dapat membantu pihak dosen dalam membuat laporan kehadiran mahasiswa dan melaporkan ke pihak universitas.

3. Aplikasi ini dapat mengurangi tindak kecurangan yang dilakukan pada saat kegiatan absensi berlangsung.

Penelitian yang penulis lakukan ini tidak lepas dari kekurangan. Oleh karena itu, untuk pengembangan sistem yang lebih baik lagi, maka diperlukan perhatian terhadap beberapa hal, diantaranya sebagai berikut:

1. Diharapkan peneliti selanjutnya melakukan penambahan fitur pada aplikasi absensi berbasis android ini untuk lebih membantu kegiatan absensi antara mahasiswa dan dosen, seperti dengan menambahkan fitur batas penyampaian materi.

2. Tampilan dari aplikasi dapat dikembangkan lagi agar mendapatkan tampilan yang lebih menarik lagi.

3. Dapat dijadikan referensi untuk dibandingkan dengan konsep yang lain dalam penelitian sejenis ataupun bahan acuan sebagai referensi penelitian.

4. Diharapkan pada pengembangan penelitian selanjutnya, terdapat fitur peringatan akan masuknya waktu kuliah, dan akan dikembangkan dalam kegiatan ujian yang berlangsung di universitas, apakah Ujian Tengah Semester (UTS) atau Ujian Akhir Semester (UAS).

\section{UCAPAN TERIMA KASIH}

Penulis mengucapkan terima kasih kepada Lembaga Penelitian dan Pengabdian Masyarakat (LPPM) Universitas Islam Riau yang telah memberi dukungan finansial terhadap penelitian ini. 


\section{DAFTAR PUSTAKA}

[1] A. Husain, A. H. A. Prastian, and A. Ramadhan, "Perancangan Sistem Absensi Online Menggunakan Android Guna Mempercepat Proses Kehadiran Karyawan Pada PT. Sintech Berkah Abadi," Technomedia J., vol. 2, no. 1, pp. 105-116, 2017, doi: 10.33050/tmj.v2i1.319.

[2] Q. Aini, Y. I. Graha, and S. R. Zuliana, "Penerapan Absensi QRCode Mahasiswa Bimbingan Belajar pada Website berbasis YII Framework," Sisfotenika, vol. 7, no. 2, p. 207, 2017, doi: 10.30700/jst.v7i2.145.

[3] R. A. Fitri Andini, Med Irzal, "PERANCANGAN DAN IMPLEMENTASI SISTEM ABSENSI ONLINE BERBASIS ANDROID DI LINGKUNGAN UNIVERSITAS NEGERI JAKARTA Anantassa Fitri Andini, Med Irzal, Ria Arafiyah Program Studi Ilmu Komputer, FMIPA UNJ," Sist. Inf., vol. 1, no. 1, pp. 1-10, 2017.

[4] R. A. Makhfuddin and N. Prabowo, "Aplikasi Absensi Menggunakan Metode Lock GPS dengan Android di PLN APP Malang Basecamp Mojokerto,” Issn, vol. 5, no. 2, pp. 55-63, 2015.

[5] T. Ramadhan and V. Utomo G, "Rancang Bangun Aplikasi Mobile Untuk," J. Teknol. Inf. dan Komunikasi, vol. 5, pp. 47-55, 2014, doi: 10.1234/JTIK.V5I2.93.

[6] L. J. Moleong, "Metodologi penelitian kualitatif," 1989.

[7] S. Margono, "Metodologi penelitian pendidikan." Jakarta: rineka cipta, 2004.

\section{BIOGRAFI PENULIS}

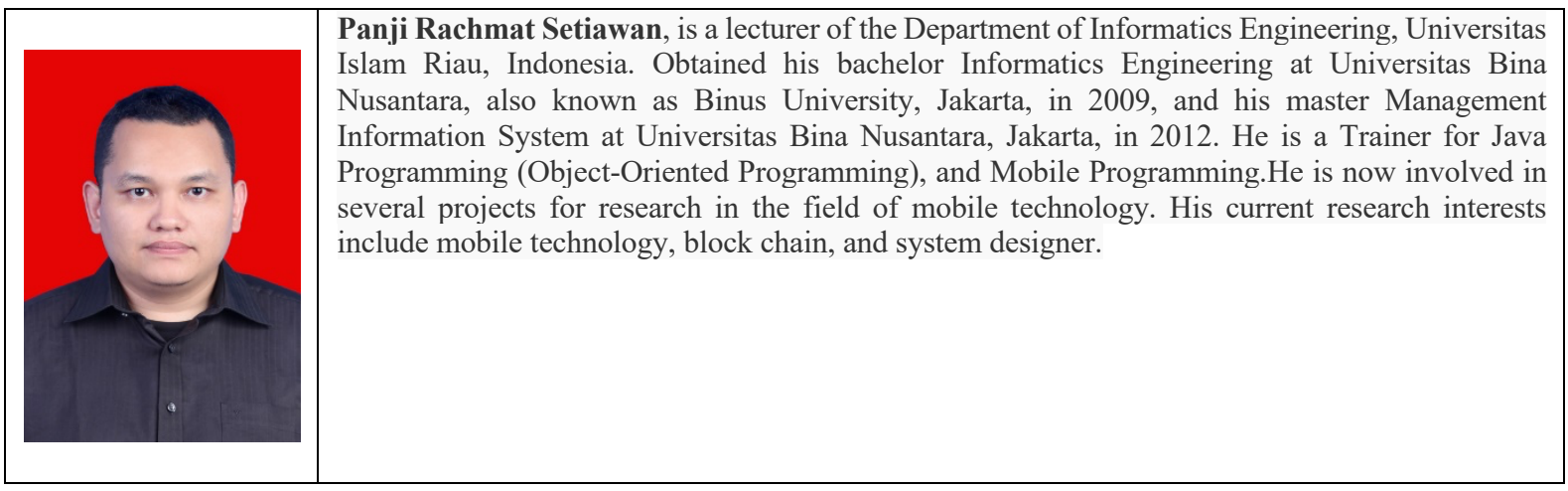

